\title{
Free Cyanide Degradation Kinetics of Cyanide Degrading Bacteria
}

\author{
L.C. Razanamahandry, L. Mekuto, V. Bazie, H. A. Andrianisa, H.Karoui, K. Meibom, M. Frutschi, \\ S.K.O. Ntwampe, R.Bernier-Latmani and H. Yacouba
}

\begin{abstract}
This study reports on the cyanide degrading bacteria (CDB) identified from artisanal mining sites and their free cyanide (FCN) degradation kinetics in aqueous medium. CDB were isolated from soil and water samples contaminated with FCN. The CDB were mainly dominated by Pseudomonas aeruginosa, Citrabacter sp., Providencia sp. (BAB-6345), Providencia staintii (Bp-40), Citrobacter sedlakii (D5) and uncultured bacterium. . FCN removal rate by these CDB varied between 95 - $99 \%$ during a $24 \mathrm{~h}$ incubation at an initial FCN concentration of $60 \mathrm{mg} \mathrm{CN}^{-} \mathrm{L}^{-1}$. The degradation kinetic studies have shown a half-saturation constant $\left(\mathrm{K}_{\mathrm{M}}\right)$, of $14 \mathrm{mmol} \mathrm{CN}^{-}$. $\mathrm{L}^{-1}$ for $\mathrm{FCN}$ and a specific activity of 28.4 mmol $\mathrm{NH}_{4}{ }^{+}$formed. $\mathrm{mol}^{-1} \mathrm{CN}^{-}$. $\mathrm{min}^{-1}$. It was conclude that various CDB are available in the artisanal mining sites and the substrate FCN is well affined with the CDB activities.
\end{abstract}

Keywords-Cyanide degrading bacteria, Free cyanide, Biodegradation kinetics

\section{INTRODUCTION}

Cyanide could be present naturally in the environment through cyano-compound producing organisms such as plants, fungi and bacteria [1]. Anthropogenic activities such as industries using metallurgical processes are still the primary

Manuscript received August 28th, 2018. The authors would like to acknowledge the Swiss Agency for Development and Cooperation to fund this research under Grant 81016359/1.

L. C. Razanamahandry was with the International Institute for Water and Environmental Engineering (2iE), Ouagadougou, Burkina Faso. She is now with the UNESCO UNISA Africa Chair in Nanoscience's/Nanotechnology Laboratories (U2AC2N), College of Graduate Studies, University of South Africa (UNISA), Muckleneuk Ridge, P O Box 392, Pretoria, South Africa and with Nanosciences African network (NANOAFNET), Materials Research Group (MRG), iThemba LABS-National Research Foundation (NRF), 1 Old Faure Road, 7129, P O Box722, Somerset West, Western Cape Province, Cape Town, South Africa.

L. Mekuto is with the Univeristy of Johannesburg, Department of Chemical Engineering, Johannesburg, South Africa.

B.V.J.T.E Bazie is with Scientific Research National Center (CNRST), Ouagadougou, Burkina Faso

H. A. Andrianisa, H. Karoui and H. Yacouba are with the International Institute for Water and Environmental Engineering (2iE), Water and Sanitation Department, Ouagadougou, Burkina Faso

K. Meibom, M.Frutschi and R.Bernier-Latmani are with the Federal Polytechnic School of Lausanne (EPFL), Environmental Microbiology Laboratory, Lausanne, Switzerland

S. K.O. Ntwampe is the founder of Bioresource Engineering Research Group (BioERG), Faculty of Applied Science Department of Biotehnology Cape Peninsula University of Technology, P.O. Box 652, Cape Town 8000, South Africa. source of cyanide disposal into the environment[2] [3][4]. The industrial effluents containing cyanide could be treated by physical, chemical and biological treatment methods. Among these treatments, biological methods are less expensive and do not create secondary hazards as it often happens during physical and chemical treatments[5] [6].

Many microorganisms were identified as able to degrade free cyanide (FCN). Some of them are pathogenic for animals and plants. Mekuto et al. [8] have reported that Klebsiella oxytoca was detected as cyanide degrading bacteria (CDB). Klebsiella oxytoca is often a cause of bronchopneumonia, urinary tract infection and septicaemia in humans [9]. Similarity, Akinpelu et al. [10] have identified the fungi Fusarium oxysporum as a microorganism that have a high potential on cyanide biodegradation. Nevertheless, many plant diseases are caused by Fusarium oxysporum such as cortical, root and fruit rots, head blights, leaf spots and vascular wilt diseases [11], [12]. These plants' diseases could affect food quality as the presence of mycotoxins in such food can be toxic to humans and animals [13] and subsequently lead to deleterious effects leading to economic losses [12].

Therefore, the identification of CDB is important prior to their application in the bioremediation of cyanide containing effluents to minimise effects on human and environmental health. CDB identification is required to control their growth during their field application [14]. Once more, CDB enzyme characteristic supports the decision on the suitability of the $\mathrm{CDB}$ and allows its performance assessment of these CDB in terms of cyanide degradation rates and the affinity between the enzyme they produced and the substrate to be degraded [15] in order to optimize the bioremediation performance.

This research reports, firstly on the identification of CDB isolated from water and soil in the artisanal small scale gold mining catchment of Burkina Faso's Zougnazagmiline and Galgouli sites and secondly, on the FCN removal kinetics by the CDB isolated.

\section{MATERIALS AND METHODS}

\section{A. $C D B$ source}

Soil and water samples from the artisanal small scale gold mining areas were collected during the dry and wet season of the years 2015 and 2016, at the catchment areas of Zougnazagmiline and Galgouli sites,. These sites were reported in Razanamahandry et al.[14]. Physico-chemical parameters such as $\mathrm{pH}$, redox potential, electrical conductivity and temperature were directly measured in-situ to ensure the reliability of the data obtained. Samples were collected in black 
plastic bags and in amber borosilicate bottles to avoid FCN volatilization. Soil and water samples were respectively stored at $4{ }^{\circ} \mathrm{C}$ to preserve the microbial flora. $\mathrm{FCN}$ concentrations were measured at laboratory scale according to pyridine pyrrazalon method by using spectrophotometer (Hach DR 5 000, Germany) at $600 \mathrm{~nm}$. CDB were isolated from the contaminated samples with a higher FCN concentration, in order to recover the most resistant bacteria.

Medium enriched by agar noble, $\mathrm{KCN}$ and various minerals salts source as reported in Oudjehani et al.[15] were used to isolate the CDB subsequent to incubation at $28{ }^{\circ} \mathrm{C}$ for 7 days[3]. The isolated CDB colonies were streaked several times on the same agar plates. Different colony morphologies were hygienically pick and inoculated in nutrient broth subsequent to incubation at $37^{\circ} \mathrm{C}$ for $24 \mathrm{~h}$, followed by organism storage at 4 ${ }^{\circ} \mathrm{C}$.

\section{B. FCN removal by isolated bacterial}

The isolated CDB were tested for their ability to biodegrade FCN. Biodegradation tests were conducted under the same conditions as that reported in Razanamahandry et al.[3], but the FCN concentration was set at $60 \mathrm{mg} \mathrm{L}^{-1}$ since the highest FCN removal rate was obtained at this FCN concentration.

\section{Morphological and Biochemical Characterization}

The CDB morphological characterization was studied by testing different cultural media which included Nutrient agar, the pigment on the nutrient agar, MacConkey's agar, Cetrimide agar, Blood agar and Deoxycholate agar. The Pseudomonas agar was also used to assess the presence of Pseudomonas species which have been detected in previous cyanide studies [16].

The biochemical characterization tests involved the use of different substrates (i.e. glucose, sucrose, lactose, xylose, maltose, mannitol) to assess the substrate utilization patterns of the isolated organisms.

The molecular characterization was realized by analyzing the genetic approach using PCR method.

\section{Molecular biological techniques}

Firstly, the DNA for each isolated bacteria was extracted by using the Promega Kit [19]. Cells were lysed by adding $600 \mu \mathrm{L}$ of the "Nuclei Lysis" solution to the isolated bacteria followed by incubation at $80^{\circ} \mathrm{C}$ for $5 \mathrm{~min}$ and left at ambient temperature. A volume $(3 \mu \mathrm{L})$ of the RNase solution was then added. After mixing for $5 \mathrm{~min}$, the mixture was incubated at $37^{\circ} \mathrm{C}$ for $35 \mathrm{~min}$ and allowed to cool to ambient temperature. The DNA of precipitated by adding $200 \mu \mathrm{L}$ of the protein precipitation solution to the cooled mixture. The mixture, containing the protein solution, was vortexed and incubated on ice for $5 \mathrm{~min}$ and then, centrifuged at 15,000 rpm for $4 \mathrm{~min}$. Thereafter, the DNA was rehydrated and precipitated again, by transferring the supernatant from the centrifuged mixture to a tube containing $600 \mu \mathrm{L}$ of isopropanol at ambient temperature and gently mixed by inversion. The mixture was centrifuged at $1500 \mathrm{rpm}$ for 1 min. The supernatant was discarded, and $600 \mu \mathrm{L}$ of $70 \%(\mathrm{v} / \mathrm{v})$ ethanol was added to the remaining portion, mixed and centrifuged in the same manner as the preceding step. Ethanol was aspirated and the resulting DNA sample was dried in open air for $15 \mathrm{~min}$. The dried DNA samples were rehydrated with $100 \mu \mathrm{L}$ of rehydration DNA solution for $1 \mathrm{~h}$ at $65^{\circ} \mathrm{C}$ followed by overnight storage at $4{ }^{\circ} \mathrm{C}$. The DNA was stored in an incubator at $-80^{\circ} \mathrm{C}$ until their amplification by PCR.

A solution of the amplification reaction, prepared under the sterilized ventilated hood was composed of: $10 \mu \mathrm{L}$ buffer $(5 \times$ phusion ${ }^{\circledR}$ HF Buffer \# B0519S), $2 \mu \mathrm{L}$ DNTPs, $2 \mu \mathrm{L}$ of the primer "forward f515", $2 \mu \mathrm{L}$ of the primer reverse r806 ", 0.65 $\mu \mathrm{L}$ of GoTaq and $32.35 \mu \mathrm{L}$ of $\mathrm{H}_{2} \mathrm{O}$ for each $1 \mu \mathrm{L}$ of each DNA sample to have a final mixture volume of $50 \mu \mathrm{L}$. Two controls were used: the negative constituted by ultrapure water and the positive by E.coli DNA.

The mixture was introduced into the PCR instrument. The PCR was then configured according to the following reaction cycle: pre-warming at $98^{\circ} \mathrm{C}$, initial denaturation for $5 \mathrm{~min}$ at $95^{\circ} \mathrm{C}$ followed by $x 30$ cycles, of $1 \mathrm{~min}$ at $50^{\circ} \mathrm{C}, 2 \mathrm{~min}$ at $50^{\circ} \mathrm{C}$ and $30 \mathrm{~min}$ at $72^{\circ} \mathrm{C}$ with a final extension of $5 \mathrm{~min}$ at $72^{\circ} \mathrm{C}$ and a constant temperature of $12^{\circ} \mathrm{C}$ until the system shut down. This cycle was repeated for $2 \mathrm{~h}$.

The DNA amplified by the PCR was then visualized using electrophoresis, at an intensity of $80 \mathrm{~mA}$. A $1 \%(\mathrm{w} / \mathrm{v})$ agarose gel which served as a support for the DNA to be visualized was prepared in 0.5 TAE. Negative and positive controls were also run on this agarose gel. The red gel was added prior to visualization producing the agarose gel image comprising the DNA bands.

The amplified DNA was inserted into a plasmid of a microorganism for purification and cloning. A ligation reaction formed by $5 \mu \mathrm{L} 2 \mathrm{X}$ Rapid Ligation Buffer, T4 DNA ligase, $1 \mu \mathrm{L}$ p GEM®-T or pGEM®-T Easy Vector (50 ng), from $3 \mu \mathrm{L}$ PCR and T4 DNA Ligase ( 3 Weiss units/ $\mu \mathrm{L}$ ) were prepared. Then, the ligation reaction mixture was incubated at ambient temperature for $1 \mathrm{~h}$. The microorganism called TOP10 was used as a transformation cell or as an amplified DNA support. A volume $(2 \mu \mathrm{L})$ of the amplified DNA was inserted into this microorganism and gently mixed. The microorganism containing the DNA amplified was then incubated on ice for 30 min and heated at $42^{\circ} \mathrm{C}$ for $30 \mathrm{sec}$ and placed again on ice for 2 $\mathrm{min}$. The microorganism was cultured in a nutrient-rich medium called SOC Medium. A volume $(250 \mu \mathrm{L})$ of this medium was added to the tube where the microorganism was present. This tube was incubated in a shaking incubator for $1 \mathrm{~h}$ at $37^{\circ} \mathrm{C}$ and at $225 \mathrm{rpm}$, with $100 \mu \mathrm{L}$ of this culture being placed in petri dishes containing Luria-Bertani (LB) medium (medium composed of: Tryptone $10 \mathrm{~g} \mathrm{~L}^{-1}$, Yeast extract $5 \mathrm{~g} \mathrm{~L}^{-1}$ and $\mathrm{NaCl} 10 \mathrm{~g} \mathrm{~L}^{-1}$ ) with ampicillin/X-Gal $(100 \mu \mathrm{g} / \mathrm{mL})$ to grow overnight in an incubator at $37^{\circ} \mathrm{C}$.

Microorganisms clone were cultured by adding $200 \mu \mathrm{L}$ of $100 \mathrm{mg} / \mathrm{mL}$ of ampicillin in $200 \mathrm{~mL}$ of the LB liquid medium to obtain a mixture of a solution of LB and ampicillin. A volume (3 $\mathrm{mL}$ ) of the LB and ampicillin solution was dispensed into $15 \mathrm{~mL}$ conical tubes to ensure that the microorganisms had sufficient dissolved oxygen. Two tubes were prepared for each sample. White colonies from two different parts of the petri dish were grown in each tube, conducted under sterile conditions. 
Afterwards, the conical tubes were placed in a shaking incubator at $37^{\circ} \mathrm{C}$ at $160 \mathrm{rpm}$.

Plasmid DNA into the microorganism clone was extracted and purified. The Promega extraction kit was used for this part of the study. First, a lysate buffer was prepared by adding $2 \mathrm{~mL}$ of the bacterial culture to a $2 \mathrm{~mL}$ microcentrifuge tube and centrifuged at maximum speed for $2 \mathrm{~min}$. To the supernatant $600 \mu \mathrm{L}$ of $\mathrm{H}_{2} \mathrm{O}$ was added to sedimented cells in the tube which were thoroughly mixed with $\mathrm{H}_{2} \mathrm{O}$ subsequent to the addition of $100 \mu \mathrm{L}$ of Lysis buffer (blue colour) followed by mixing by inverting the tube 6 times. A neutral solution $(350 \mu \mathrm{L})$ between 4 to $8^{\circ} \mathrm{C}$ of neutralization was added and mixed by inverting the tube until a yellow solution was obtained. The tubes were then centrifuged at maximum speed using a microcentrifuge (Eppendorf, Germany) for $3 \mathrm{~min}$. The supernatant was transferred to a pure tube with a mini-column, the "PureYieldTM Minicolumn (Promega)", without distributing cells to the bottom of the tube. The mini-column tube was centrifuged at a maximum speed for $30 \mathrm{sec}$. Thereafter, the liquid that passed through the mini-column was aliquoted out with the mini-column being put back into the same collection tube. Then, the mini-column was washed by adding $200 \mu \mathrm{L}$ of "Endotoxin Removal Wash (ERB)" and centrifuged at maximum speed for $30 \mathrm{sec}$ and the resultant liquid was decanted. The $400 \mu \mathrm{L}$ of the "column wash solution (CWC)" was added to the mini-column and centrifuged for $30 \mathrm{sec}$. Finally, the plasmid DNA was eluted by transferring the mini-column into a sterile $1.5 \mathrm{~mL}$ tube, then $30 \mu \mathrm{L}$ of the buffer elution solution was directly added to the mini-matrix column and allowed to rest for $1 \mathrm{~min}$ at ambient temperature. After 1 min, the mini-column with the $1.5 \mathrm{~mL}$ tube was centrifuged for $30 \mathrm{sec}$ to elute the plasmid DNA.

\section{E. Identification of the Isolates}

Volumes $(12 \mu \mathrm{L})$ of the plasmid DNA were transferred to a $1.5 \mathrm{~mL}$ tube which was sent to Microsynth, a Next Generation Sequencing company, for DNA sequencing. The capillary electrophoresis method was applied using "Sanger cycle sequencing" equipment. The remainder of the eluted DNA was stored at $-20^{\circ} \mathrm{C}$. The primer used for sequencing is the $\mathrm{T} 7$ provided by Microsynth.

The sequencing procedure was done according to Microsynth in-house procedures, which made use of the Sanger cycle sequencing method. The resultant sequences were compared using the Basic Local Alignment Search Tool (BLAST) site (https://blast.ncbi.nlm.nih.gov/Blast.cgi). The program compares the sequence of nucleotides or proteins and gives the statistical significance of each comparison. Software MEGA version 6.0 was used to MEGA version 6.0 was used to construct the phylogenetic trees.

\section{F. FCN Removal Kinetics Studies}

Eight $(\mathrm{n}=8)$ liquid media formed by at varying $\mathrm{FCN}$ concentrations of 10, 20, 30, 40, 50, 60, 70, and $80 \mathrm{mg} / \mathrm{L}$ using the media described in Razanamahandry et al [3]. A volume (1 $\mathrm{mL}$ ) of the $\mathrm{CDB}$ colonies being added to each medium and stirred thereafter. A volume $(35 \mathrm{~mL})$ of the BDC mixture and cyanide solution were analysed for the cyanide concentration, while the density of the living $\mathrm{BDC}$ and $\mathrm{NH}_{4}{ }^{+}$production at the initial phase were tested (at $\mathrm{t}=0 \mathrm{~min}$ ) and the final phase (at $\mathrm{t}=$ $10 \mathrm{~min}$ ) being determined. A kinetic model was then established from the measured parameters. The kinetic model described by Michaelis-Menten was used according to Eq. 1:

$$
v=-\frac{d S}{d t}=\frac{d P}{d t}=\frac{v_{\max } S}{K_{M}+S}
$$

Where:

v : initial rate in the absence of product of the enzymatic reaction for a concentration of susbtrate $(S)$ which is the concentration of free cyanide $\left(\mathrm{mol} \mathrm{min}^{-1}\right)$,

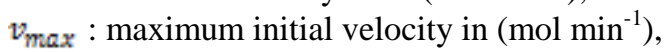

$K_{M}$ : Michaelis constant is the concentration in $(S)$ for which $v=\frac{W_{\max }}{2}\left(\mathrm{~mol} \mathrm{~L}^{-1}\right)$,

$P$ : concentration of the product which is $\mathrm{NH}_{4}{ }^{+}$and

$v_{\max }$ and $K_{M}$ express the characteristics of the enzyme and were determined using the Lineweaver-Burk curve with $\mathrm{y}=1 / v$ and $x=1 / S$ whereby $v_{\max }=1 / b$ and $K_{M}=a / b$.

with $a$ and $b$ being coefficients of the linear trend curve of the Lineweaver-Burk curve $y=a x+b$.

\section{RESULTS AND DISCUSSION}

\section{A. CDB Isolated and FCN Removal Rate}

Thirty-five $(\mathrm{n}=35)$ isolates were obtained and coded according to: (i) the source (Zougnazagmiline or Galgouli site), (ii) the sample type (water or soil), (iii) the season and the year of sample collection (dry season or wet season, year 2015 or 2016), and (iv) forms of colonies of individual species in petri dishes.

The isolated CDB demonstrated FCN biodegradation capabilities with a removal rate of $99 \%$ after $24 \mathrm{~h}$ and a biodegradation rate ranging from 0.15 to $39.42 \mathrm{~mol} \mathrm{CN}^{-} \mathrm{min}^{-1}$ Bacterium $^{-1}$ where determined to be suitable for this study. As results of morphological and biochemical studies, Table 1 shows the CDB species isolated, that were detected, which include: Pseudomonas sp., Klebsiella sp., Staphylococcus sp., Providencia sp., Serratia sp. and Citrobacter sp.

The bacteria in the water at both sites were identified: Pseudomonas sp., Klebsiella pneumoniae, Providencia sp. and Providencia thailandensis. These species were also identified in the soil at both sites with the dominance of the Pseudomonas aeruginosa, Citrobacter sedlakii, Serratia sp., Klebsiella oxytoca, Providencia stuartii and Staphylococcus sp. The same species appeared regardless of the different season and year of the collected sample.

The species Klebsiella pneumoniae, Pseudomonas aeruginosa, Serratia sp., Klebsiella oxytoca and Staphylococcus sp. have been proven in the literature to be cyanide degraders [20]-[22]. 
TABLE I: CDB SPECIES ISOLATED

\begin{tabular}{|l|l|l|}
\hline Sites & Sample type & Species \\
\hline Zougnazagmiline & Water & $\begin{array}{l}\text { Klebsiella pneumoniae, } \\
\text { Pseudomonas } \text { sp. }\end{array}$ \\
\hline & & Providencia sp. \\
\hline & Soil & Klebsiella oxytoca, \\
\hline & & Providencia stuartii \\
\hline & & Pseudomonas sp. \\
\hline & & Staphylococcus sp. \\
\hline & Water & Providencia sp. \\
\hline & & $\begin{array}{l}\text { Klebsiella pneumoniae } \\
\text { Providencia thailandensis }\end{array}$ \\
\hline & & Pseudomonas aeruginosa \\
\hline & & Citrobacter sedlakii \\
\hline & & Klebsiella oxytoca \\
\hline & & Serratia sp. \\
\hline & &
\end{tabular}

\section{B. CDB Identification by DNA Sequencing}

The concentration of the extracted DNA ranged from 29.5 to $792.5 \mu \mathrm{g} \mathrm{mL}^{-1}$. The purity of the DNA was also verified from the ratio DNA/RNA and DNA/Proteins which were close to 2 . Fig. 1 shows the result of the amplification of some DNA samples (MP, EI, NF, FI and EC) by PCR with both negative and positive controls. All DNA bands had a base pair of 291 which proved the conformity between the primers (R806 - F515 $=291$ ) used and the DNA sample studied. The negative control also demonstrated that the sample had not been contaminated during preparation. These were the desired DNA bands required and were confirmed by the positive control. The isolates $(\mathrm{n}=$ 35) were formed by 10 species of bacteria from the sample collection sites. Table 2 summarizes the link between these isolates and the identified species. All identified CDB species were directly related (99\%) similar identity and $100 \%$ recovery rate to the isolates in the repository. The species obtained were also marked by a Providencia sp. type dominance.

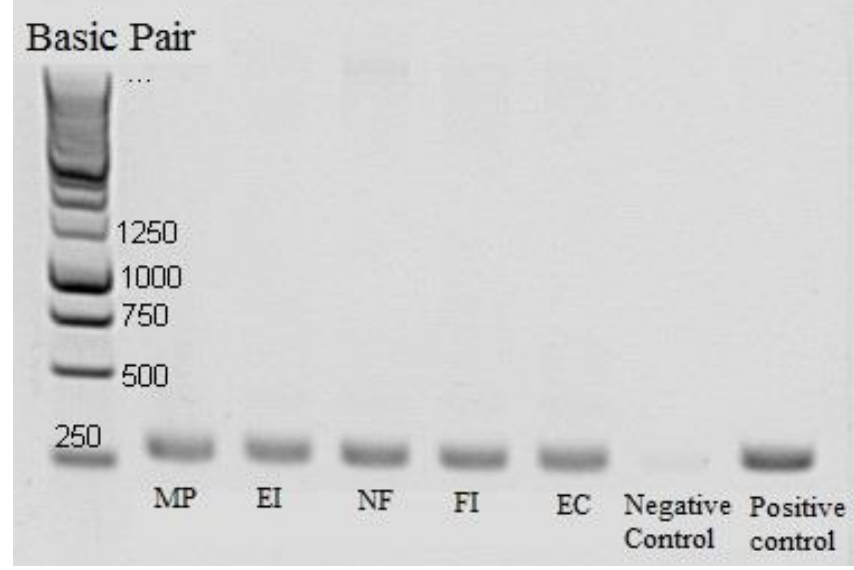

Fig. 1 DNA amplified visualized through the agarose gel

Fig. 2 and 3 show the phylogenetic tree of species of bacteria present in water and soil samples from each study site. Bacteria $(n=10)$ were detected from the two sites (Zougnazagmiline and
Galgouli). The samples were composed of: Uncultured TABLE II: CDB SPECIES IDENTIFIED BY DNA SEQUENCING

\begin{tabular}{|l|r|r|l|}
\hline Isolate Codes & $\begin{array}{l}\text { Identity } \\
(\%)\end{array}$ & $\begin{array}{l}\text { Recovery } \\
(\%)\end{array}$ & Species \\
\hline MP, EI & 99 & 100 & $\begin{array}{l}\text { Uncultured bacterium clone } \\
\text { (OTU7) }\end{array}$ \\
\hline NF, FI, EC & 99 & 100 & Uncultured bacterium \\
\hline $\begin{array}{l}\text { BP,HF, } \\
\text { FF, KC,CF }\end{array}$ & 99 & 100 & $\begin{array}{l}\text { Providencia } \text { sp. } \\
\text { (BAB-6345) }\end{array}$ \\
\hline $\begin{array}{l}\text { GR, NC, IC, } \\
\text { CI, FC, LC, } \\
\text { DI, BC }\end{array}$ & 99 & 100 & $\begin{array}{l}\text { Providencia stuartii } \\
\text { (MRB-44) }\end{array}$ \\
\hline $\begin{array}{l}\text { CC, EF, JE, } \\
\text { JI, GC }\end{array}$ & 99 & 100 & $\begin{array}{l}\text { Providencia stuartii } \\
\text { (Bp-40) }\end{array}$ \\
\hline DR, IN, DC & 99 & 100 & $\begin{array}{l}\text { Uncultured bacterium clone } \\
\text { (LIB049 C04 1646) }\end{array}$ \\
\hline IP,OF, HI & 99 & 100 & Providencia sp.(BAB-6345) \\
\hline MC, LP, BI & 99 & 100 & Pseudomonas aeruginosa \\
\hline OP & 99 & 100 & Citrobacter sedlakii (D5) \\
\hline AC, AP & 99 & 100 & $\begin{array}{l}\text { Uncultured bacterium clone } \\
\text { (Otu01369) }\end{array}$ \\
\hline
\end{tabular}

bacterium clone (OTU7),Uncultured bacterium, Providencia sp. (BAB-6345), Providencia stuartii (MRB-44), Providencia stuartii (Bp-40), Uncultured bacterium clone (LIB049 C04 1646), Providencia sp. (BAB-6345), Pseudomonas aeruginosa, Citrobacter sedlaki (D5) and Uncultured bacterium clone (Otu01369).

There were common species at these 2 sites; these were formed by: Uncultured bacterium clone (OTU7), Uncultured bacterium and Providencia sp. (BAB-6345). The composition of the culture medium of two first species is still unknown. They are likely to be new species. These three species were all present in the water of the two sites, but the species Uncultured bacterium clone (LIB049 C04 1646) was added for the case of Galgouli.

The species of bacteria present in the soil were much diversified for the Galgouli site compared to those of Zougnazagmiline. In Galgouli, the bacteria identified were: Uncultured bacterium clone (OTU7), Uncultured bacterium, and Pseudomonas aeruginosa, Citrobacter sedlakii (D5) and Uncultured bacterium clone (Otu01369), while at Zougnazagmiline, they were: Uncultured bacterium clone OTU7, Uncultured bacterium, Providencia stuartii (MRB-44) and Providencia stuartii (Bp-40).

Based on the ability of these 10 identified species to degrade cyanide, 4 groups of bacteria can be obtained according to Fig. 4.

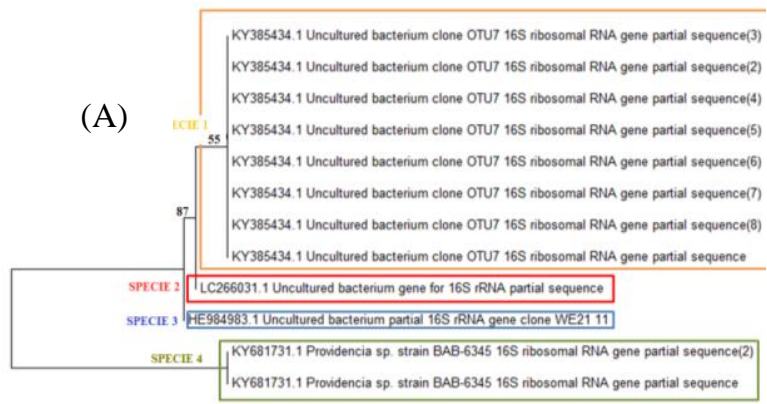

5 


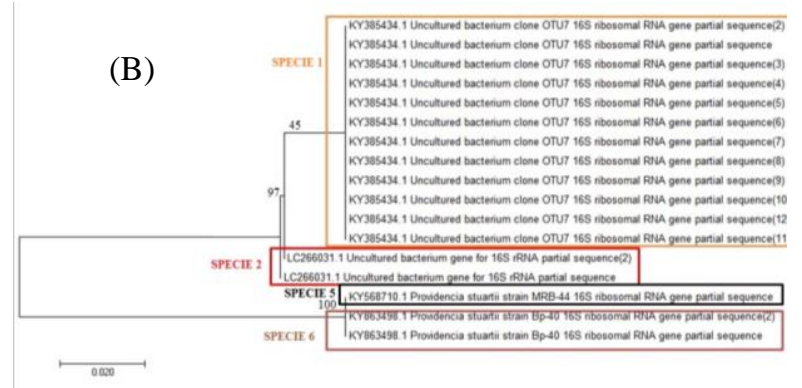

Fig. 2 Phylogenetic Trees of CDB species in Zougnazagmiline sites

(A) from water samples (B) from soil samples

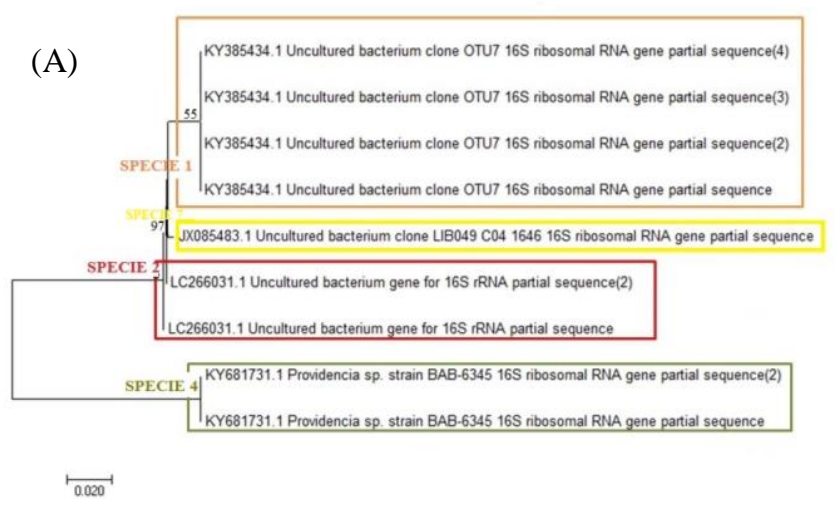

(B)

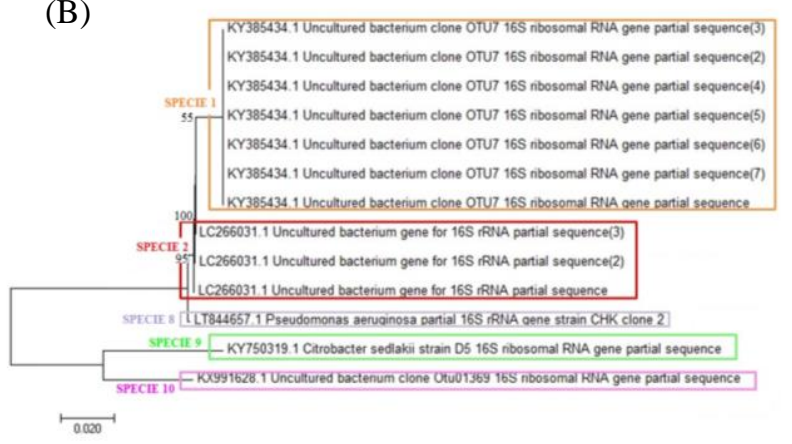

Fig. 3 Phylogenetic Trees of CDB species in Galgouli sites (A) from water samples (B) from soil samples

Among these species, Pseudomonas aeruginosa has been reported by [18] as a soil-inhabiting species capable of degrading cyanide. Ibrahim et al. [1] also shown the faculty of the genus Citrabacter sp. to degrade total cyanide, especially metal cyanide. Nevertheless, minimal studies have shown the ability of the following species to degrade cyanide: Providencia sp. (BAB-6345), Providencia staintii (Bp-40) and Citrobacter sedlakii (D5). However, Mekuto et al. [8] have recently reported the ability of Providencia sp. to degrade FCN.

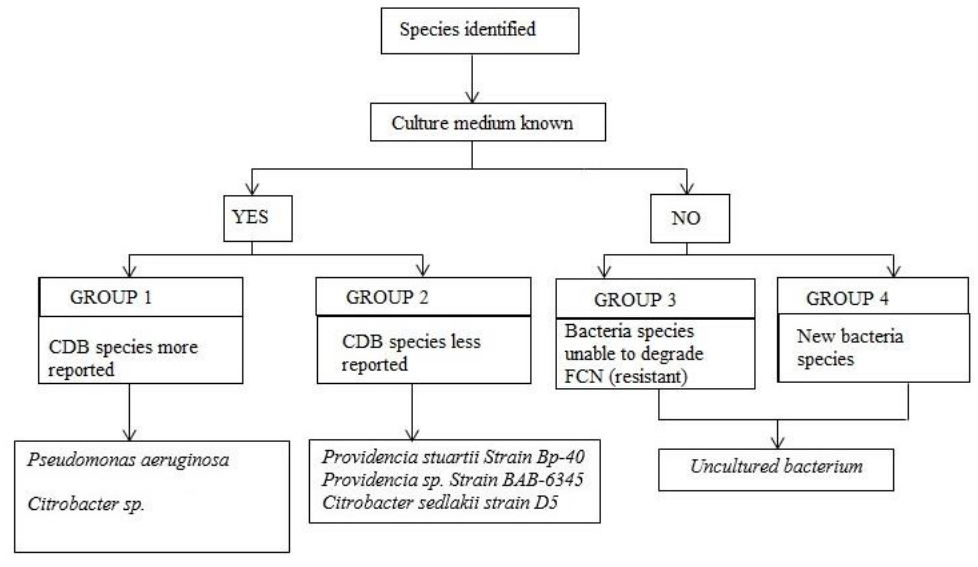

Fig. 4 Classification of the ten CDB species identified based on the CDB already reported

\section{FCN Removal Kinetics}

Fig. 5 presents the Michaelis- Menten kinetic parameters' values, which describes enzymatic activity kinetics when the tested FCN concentrations have been increased. A linear regression analysis, using Lineweaver-Burk type linearization (Fig. 6b), showed a FCN half saturation constant $\left(\mathrm{K}_{M}\right)$ of 14 $\mathrm{mM}$. In addition, CDB tested have revealed $28.4 \mathrm{mmol} \mathrm{NH}_{4}^{+}$ formed $\mathrm{mol}^{-1} \mathrm{CN}^{-}$initial $\mathrm{min}^{-1}$ as a value of the specific activity of enzymes produced by these species.

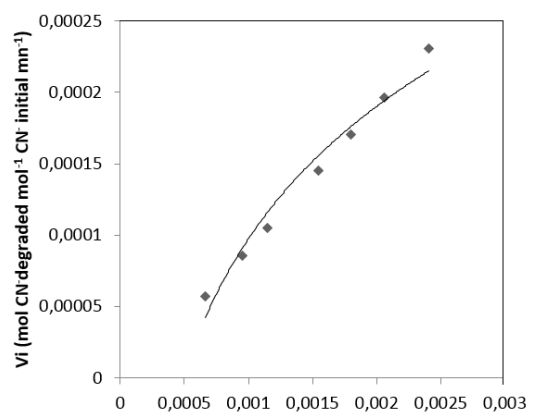

[CN-] initial $\left(\mathrm{mol} \mathrm{L}^{-1}\right)$

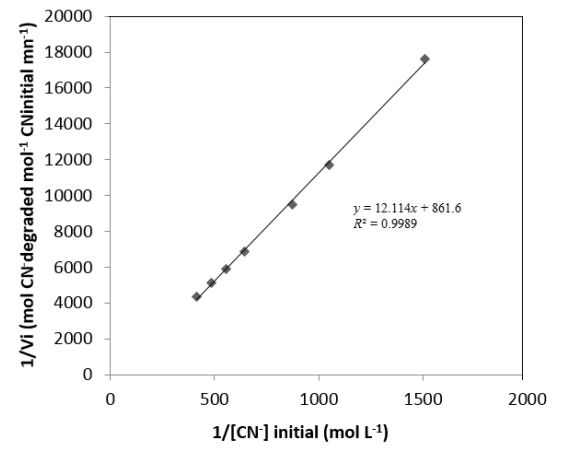

(B)

$\mathrm{V}_{\text {max }}=1.16 \mathrm{mmol} \mathrm{CN}^{-}$degraded $\mathrm{mol}^{-1} \mathrm{CN}^{-}$initial $\min ^{-1}$ $\mathrm{K}_{M}=14 \mathrm{mM} \mathrm{CN}^{-}$degraded

Fig. 5 Michaelis-Menten parameters for FCN degraded (A) Non-linear regression, (B) Lineweaver- Burk

\section{CONCLUSION}

Various CDB were identified from water and soil samples contaminated by FCN from mining areas in Burkina Faso's 
Zougnazagmiline and Galgouli sites. Ten $(\mathrm{n}=10)$ bacteria species were obtained in which new CDB were detected and new microorganisms species were suspected. The affinity between the FCN substrate and the CDB enzyme was revealed by the FCN removal kinetics. Future works should be focused on the field application of the CDB identified.

\section{REFERENCES}

[1] K. K. Ibrahim, M. A. Syed, and M. Y. Shukor, "Biological remediation of cyanide: a review," Biotropia (Bogor)., vol. 22, no. 2, pp. 151-163, 2015.

[2] L. Mekuto, V. A. Jackson, and S. K. O. Ntwampe, "Biodegradation of Free Cyanide Using Bacillus Sp . Consortium Dominated by Bacillus Safensis , Lichenformis and Tequilensis Strains : A Bioprocess Supported Solely with Whey," Bioremediation Biodegrad., no. 18, pp. 1 -7, 2013.

[3] L. C. Razanamahandry, H. A. Andrianisa, H. Karoui, K. M. Kouakou, and H. Yacouba, "Biodegradation of free cyanide by bacterial species isolated from cyanide-contaminated artisanal gold mining catchment area in Burkina Faso," Chemosphere, vol. 157, pp. 71-78, 2016. https://doi.org/10.1016/j.chemosphere.2016.05.020

[4] L. C. Razanamahandry, H. Karoui, H. A. Andrianisa, and H. Yacouba, "Bioremediation of soil and water polluted by cyanide: A review," African J. Environ. Sci. Technol., vol. 11, no. 6, pp. 272-291, 2017. https://doi.org/10.5897/AJEST2016.2264

[5] Y. Ozel et al., "New fungal biomasses for cyanide biodegradation," $J$ Biosci Bioeng, vol. 110, no. 4, pp. 431 -435, 2010. https://doi.org/10.1016/j.jbiosc.2010.04.011

[6] Y. K. Özel et al., "New fungal biomasses for cyanide biodegradation," $J$. Biosci. Bioeng., vol. 110, no. 4, pp. 431-435, Oct. 2010. https://doi.org/10.1016/j.jbiosc.2010.04.011

[7] P. Gupta, T. R. Sreekrishnan, and Z. A. Shaikh, "Application of hybrid anaerobic reactor: Treatment of increasing cyanide containing effluents and microbial composition identification," J. Environ. Manage., vol. 226, no. August, pp. 448-456, 2018. https://doi.org/10.1016/j.jenvman.2018.08.023

[8] L. Mekuto, S. K. O. Ntwampe, and J. B. N. Mudumbi, "Microbial communities associated with the co-metabolism of free cyanide and thiocyanate under alkaline conditions," 3 Biotech, vol. 8, no. 93, pp. https://doi.org/10.1007/s13205-018-1124-3, 2018.

[9] L. Singh, M. P. Cariappa, and M. Kaur, "Klebsiella oxytoca: An emerging pathogen?," Med. J. Armed Forces India, vol. 72, pp. S59-S61, 2016.

[10] E. A. Akinpelu, A. T. Adetunji, S. Karabo, O. Ntwampe, F. Nchu, and L. Mekuto, "Performance of Fusarium oxysporum EKT01 / 02 isolate in cyanide biodegradation system," vol. 23, no. 2, pp. 223-227, 2018.

[11] P.E. Nelson, "Life cycle and epidemiology of Fusarium oxysporum," in Fungal Wilt Diseases of Plants, Academic Press, Inc., 1981, pp. 51-80. https://doi.org/10.1016/B978-0-12-464450-2.50008-5

[12] I. Plavšin, M. Velki, S. Ečimović, K. Vrandečić, and J. Ćosić, “Inhibitory effect of earthworm coelomic fluid on growth of the plant parasitic fungus Fusarium oxysporum," Eur. J. Soil Biol., vol. 78, pp. 1-6, 2017. https://doi.org/10.1016/j.ejsobi.2016.11.004

[13] C. A. Chilaka, M. De Boevre, O. O. Atanda, and S. De Saeger, "Fate of Fusarium mycotoxins during processing of Nigerian traditional infant foods (ogi and soybean powder)," Food Res. Int., p. doi:10.1016/j.foodres.2018.08.055, 2018.

[14] V. M. Luque-Almagro et al., "Characterization of the Pseudomonas pseudoalcaligenes CECT5344 Cyanase, an enzyme that is not essential for cyanide assimilation.," Appl. Environ. Microbiol., vol. 74, no. 20, pp. 6280-6288, Oct. 2008. https://doi.org/10.1128/AEM.00916-08

[15] N. Gupta, C. Balomajumder, and V. K. Agarwal, "Enzymatic mechanism and biochemistry for cyanide degradation: a review.," J. Hazard. Mater., vol. 176, no. 1-3, pp. 1-13, Apr. 2010. https://doi.org/10.1016/j.jhazmat.2009.11.038

[16] L. C. Razanamahandry, H. A. Andrianisa, H. Karoui, J. Podgorski, and H. Yacouba, "Prediction model for cyanide soil pollution in artisanal gold mining area by using logistic regression," Catena, vol. 162, pp. 40-50, 2018 https://doi.org/10.1016/j.catena.2017.11.018

[17] K. Oudjehani, G. J. Zagury, and L. Deschênes, "Natural attenuation potential of cyanide via microbial activity in mine tailings.," Appl.
Microbiol. Biotechnol., vol. 58, no. 3, pp. 409-15, Mar. 2002. https://doi.org/10.1007/s00253-001-0887-2

[18] P. V. Parmar, P.;Soni, A.;Vyas, K., Desai, "Isolation and characterization of cyanide degrading bacterial strains from contaminated soil," Int. J. Environ. Sci., vol. 2, no. 4, pp. 2006-2014, 2012.

[19] Promega Corporation, Wizard Genomic DNA Purification Kit Quick Protocol, FB022. Printed in USA, Revised 10/10, 2010.

[20] V. M. Luque-Almagro, R. Blasco, M. Martínez-Luque, C. Moreno-Vivián, F. Castillo, and M. D. Roldán, "Bacterial cyanide degradation is under review: Pseudomonas pseudoalcaligenes CECT5344, a case of an alkaliphilic cyanotroph.," Biochem. Soc. Trans., vol. 39, no. 1, pp. 269-74, Jan. 2011. https://doi.org/10.1042/BST0390269

[21] V. Kumar, V. Kumar, and T. C. Bhalla, "In vitro cyanide degradation by Serretia marcescens RL2b," Int. J. Environ. Sci., vol. 3, no. 6, pp. 1969-1979, 2013.

[22] P. Tang, Y.-C. Hseu, H.-H. Chou, K.-Y. Huang, and S. C. Chen, "Proteomic Analysis of the Effect of Cyanide on Klebsiella oxytoca," Curr. Microbiol., vol. 60, no. 3, pp. 224-228, 2010.

https://doi.org/10.1007/s00284-009-9529-1

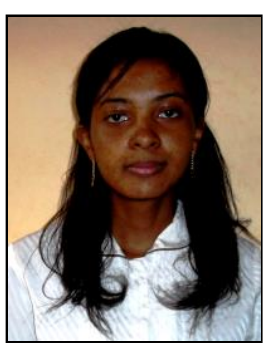

C.L. Razanamahandry was born in Betroka Madagascar in 1989. She is holder of both a Master of Agronomy, Water and Forest option from Superior School of Agronomic Science (ESSA) in 2013, Antananarivo, Madagascar and a Master of Hydraulics from Superior Polytechnic School of Antananarivo (ESPA) and the International Institute for Water and Environmental Engineering under a mobility program in 2014. She has done her $\mathrm{PhD}$ on Cyanide Environmental pollution generated by the artisanal gold mining activities and its bioremediation at the International Institute for Water and Environmental Engineering, Ouagadougou, Burkina Faso, receiving her $\mathrm{PhD}$ degree in Water and Environmental Science in 2017.

Currently, she is doing her full Post-Doctoral fellowship on the application of green nanoparticles on the mining wastewater treatment, at iThemba-LABS, Cape Town, South Africa and have got a contract as an international Consultant on Environmental and Engineering field agent and she is currently an associate member of Bioresource Engineering Research Group (BioERG) at the Faculty of Applied Science, Department of Biotehnology, Cape Peninsula University of Technology, Cape Town, South Africa.

Dr. Razanamahandry is a fellow of Union European under PIMASO program, a fellow of Swiss Cooperation for Development, a fellow of National Research Foundation and TWAS. She has participated in numerous oral presentations around the world (Burkina Faso, Tunisia, Senegal, Switzerland, Mexico, and Australia) and published four papers in various Elsevier Ltd. journals such as Chemosphere (2016), Catena (2018) and Data in Brief (2018) and in regional Academic journal such as the African Journal of Environmental Science and Technology (2017).. 